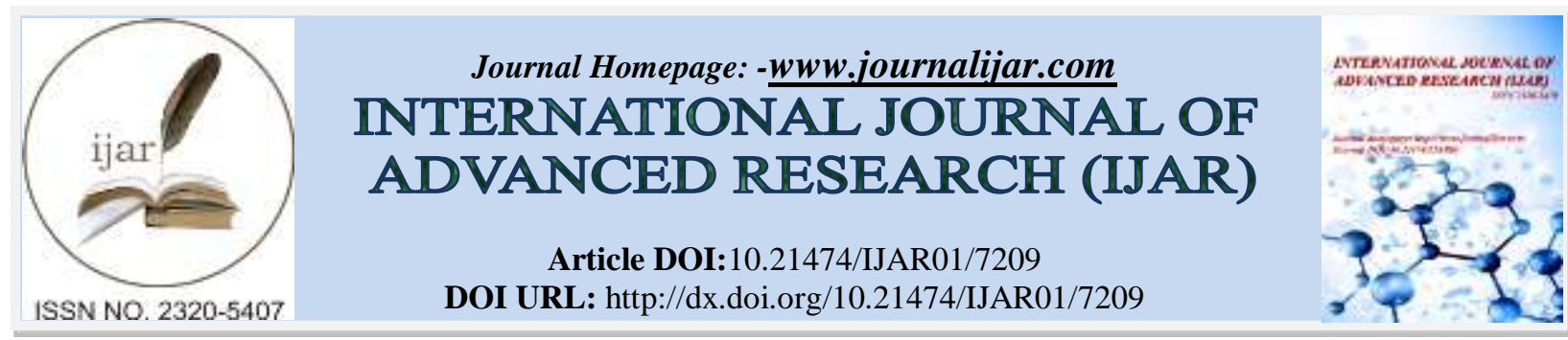

RESEARCH ARTICLE

\title{
THE EXISTANCE OF GAYONESS WATER-PITCHER DURING AND AFTER ARMED CONFLICT IN SOCIAL CONTEXT.
}

Rida Safuan Selian.

\section{Manuscript Info}

(..........................

Manuscript History

Received: 05 April 2018

Final Accepted: 07 May 2018

Published: June 2018

Keywords:-

Gayoness Water-Pitcher, Armed conflict, Gayoness society

\section{Abstract}

The goal of this research is to know the existance of Gayoness water pitcher in society after armed conflict that happened in Aceh Province between Aceh Freedom Movement (GAM) and Indonesia Army (TNI). This research use qualitatif approach which done to the gayoness community, Central Aceh District. Data collected through observation, interview and semi structure and also documentation. The sources are water-pitcher craftmans, Acehness cultural council (MAA), public figures and also Gayoness. According to research result, Gayoness pithcer is a craft that use character or feature of gayoness culture. Gayoness pitcher with feature or characteristic of Gayoness culture that use the motif of elements which distilitation from the form of plantations, natures, things and geometric patterns. In connection with armed conflict which occur in Aceh Between Aceh Freedom Movement (GAM) and Indonesia Army (TNI) that influence significantly to the community of Gayoness water-pitcher craftsman. During the conflict, it's rarely for Gayoness water-pitcher craftmans got the training from the related part such as industry affair department. The decrease of numbers of gayoness water-pitcher caused by the fright the felt to go outside to find the material for water-pitcher making. Beside, when armed conflict era in Aceh number of tourist, domestic or international, who visiting Gayoness highland decrease significantly that influence the gayoness pitcher handicraft marketing.

Copy Right, IJAR, 2018,. All rights reserved.

\section{Introduction:-}

Gayoness ethnic of Aceh lives in highland area and most of them are farmers. Traditional handicraft of Gayoness water-pitcher which produced by craftman have norms, philosophies and informal education which is one of gayoness culture that examined needed inside family and environment.

Culture is all of complexity that include knowledge, faith, art, law, moral, character and others ability gained by human as society member ( Sir Edward, 1897, derive from William A. Haviland, Culture Essence, 1995)

Culture can be said astendency in society life. Culture can be differenciated ito 3 tendency of culture, there are:

1. Ideas as the complexity from ideas, concepts, values, norms, and principles. Human ideas or concepts that live in society has abstract characteristic. These ideas or concepts are not seperated each other, they are tightly connected became a system called cultural system. 
2. Activity as cultural form also human patterned action. Those action called social system, consists of human interacted activities, relations and associationone to another followed certain pattern and behaviour order.

3. Artifact were human handmade things. It's also called as physical cultural because it produced from activities, actions and the outcome of all people in the community (Koentjaraningrat, 1988).

Gayoness highland is one of tourist destination which has beutiful nature scenery and carpet of coffee farm, also art handicraft production that drawn tourist. Gayoness cultural symbols are included into various of Gayoness art and cultural creation.

Remembering that Aceh had been suffering long enough because of longterm conflict with millitary emergency operation took place against Aceh Freedom Movement (GAM) rebellion from 1976 to 2004 (Edwin Thumboo, 1985), also great earthquake and tsunami that attacked this area violently on December 26, 2004 cause of Aceh social values and cultural in general and specially Gayoness social values which based on Islam faded (D. Kemalawati and Sulaiman, 2005).

From different aspect, a great earthquake and tsunami gave a place for peace between GAM and Indonesia Government. It also gave an opportunity to international society to came and gave various aids for rehabilitation and reconstruction of Aceh development. Longterm conflict and the arrival of international communities after cocnflict and Tsunami influenced the local natural culture made local people adjust their culture (Koentjaraningrat, 1990).

Thus with Gayoness pitcher handicraft as one of Gayoness cultural outcome which contain norms, philosophies and informal education values that socialized needed in the families and communities because of it big role in cultural resistance and it eternality. Based on description above, the big problem is how the existance of Gayoness waterpitcher during and after armed conflict in social context.

\section{Theoritical review:- \\ Cultural and Community:-}

Early definition about cultural was definition that submitted by Edward B Taylor in 1874 in his book 'Primitive Culture'. According to Taylor, cultural isthe complexity which summarize all the knowledges, faith or religion, art, morality, laws, tradition, ability and others customs needed by human as part of community. This cultural definition by Taylor now widely comprehended. Simpler definition but still summarize all aspects was definition pointed by Adamson Hoebel in his book 'The study of Man'(1972), said that cultural is integration of various behaviour of study result system as the unique characteristic of community and as non biology inheritance ( in Joyomartono 1991).

From this definition we know that cultural is not biological inheritance. Cultural was inherited from generation to next generation through study process. Cultural owned together by most of community member and each of community has their own culture.

There are values system inside the culture. This cultural values system plianted by most of community members. It's function as the highest manual of human behaviour. Other form of human manner behaviour systems were more concrete such as special regulations, laws and norms that all oriented on cultural value system (Kaplan 1999).

Cultural as anthropological object which cover family and socialorganitation, education, technology, economy, religion, languange, art, and mithology (Kapaln 1999). Cultural in definition were, 1) cultural changed from one generation to other generation, cultural as social tradition inheritance, 2) cultural were studied, 3) cultural was full sensationed and owned by it supported community (Rohidi 2000).

Handicraft Art in community life

Handicraft is the barnch of fine art that very high skillfull needed such as carved, earthenware or sherd cane work, textile and many others. Craftman is an artist who has tehnical skill. Soedarso SP (1999) said that handicraft art is outcome of artwork based on craftmanship, art which exposes the expertise of the man who made it.

Handicraft is an art activity that based on the competency of hand and function to proccess the material can be found often in the environment changed not only have purpose values but also esthethic value. This handicraft art can borrowed many knowledges in fine art such as the way to make sculpture or carving to produce thing, however still 
not attentively focused on the emotional satisfaction like painting and sculpture outcome. Handicraft art also followed the tradition more often than discoveried which is often discover by an artist individually.

Definition of handicratf art is still become the topic that debated continuilly until now. There were some different opinions which can be understand because each of opinion has different point of view and approach.

Meanwhile the definition of craftmans is an artist who has technical skill. More over SP. Gustami explain as follow: "what handicraft means in this study is the unique outcome of artwork which has the characteristic that contain the staedy and deeplycapacity of values inside that connected with esthethic value, symbolic, philosophy and it's function. Because of that it's supported by high skill (craftman) in formed, consequenly the present of handicraft included in valuable art collection. Further, those past period of handicraft art now predicated as traditional art.

Any further expressed by SP Gustami as follow:

" the terminology of habdicraft art was bore from the level of social class which present the dualism of culture in society, great culture in large tradition development inside the palace wall in the circle of nobles. While minor culture were lived inside small tradition which develop outside the palace wall. The terminology of skilled art bore from large tradition to call the outcome of artwork which produced by craftman inside the palace. Meanwhile the termonilogy of handicraft for small tradition craftman outcome, while the place where the activity was done called handicraft village, because of that this terminology is more sociable".

Definition of skilled art often classified same as handicraft. The terminology of handicraft art also often related with art purpose with special characteristic based on decorative purpose that supported by high technical skill in it's performance.

Handicratf art often senses as one of art branch which more focused in hand skill with decorative purpose because supported by high technical skill. In reality, the fom of handicraft art showed the fullfill of functional practice and esthetic expressions inside the complete and solid unity.

In that context handicraft art were not functional rational opinion parted with esthetic expression, but rather the asimilation of the handicraft art creativity work outcome based on art and design in the complete unit (Gusami, 2001).

Next But Muchtar (1991) chatagorized handicraft art into two chatagories there were: first chatagory is an outcome of handicraft work which sustain the definition of handicraft in conventional way, there is handicraft art as an object of daily neccesities. Those handicraft doer in this chatagory were dilligently and continuily perform the handicraft things like how they inherited from their ancestor. There are no even a tiny differenciate among them, but that also the effort to develop handicraft become more qualitated than before. Second chatagory is the one who saw the handicraft art as an object to surpress individual expression until the maker called themselves as handicraftman.

Based on several definitions above, we can conclude that handicraft art is something that done with tendency more involving of skill ability and competency whose produced by skillfull hand and also decorate characteristic or in performance it made with full sense of art and often has practce function or useful as product.

The next development of handicraft art in the process were permitted to use tolls aid as long as in the process the craftman are able control all the process fully.

\section{Conflict in society:-}

Conflict is the unseperated part of communication and live. Conflict can developed if there were differenciated in comprehension or misunderstanding but it could also as the representative of reason in discussion or disagreement.however, conflict is not always a bad things.

Conflict can give little explanation about the meaning of differenciation. In natural differenciations, the defferenciated between man and woman, traditions, values, rules, differenciated of interest and also comprehension about something that had been spoken o done. We all are live in a social system with different values, tradition even climate. 
If we are agree one to another or have dfferent thing, conflict could be created easily because most of the man has created a singular solution tendency. Therefor,if other person has a valid reason to look or think differently, it become difficult thing to accepted.

When we got injured in conflict, we have the tendency to acted the same, until other person also got injured, for example doing bad thing for instance through act or declaration such as:

1. Discern the mistake only in our part.

2. Discern the mistake only in other part.

3. Discern our feeling and needed.

4. Diccern other feeling and needed.

With just the two first things, we already included in the level of prolong the conflict. These explanation can also use in a war. War is often unsolved conflict product. In the beginning it could be caused by misunderstanding or disagreement or even differenciated of view and the competetion of interest. War is form of conflict use armed cause the lost of souls and properties, phisical and mentaly damage from the victim. War is fighting and destroying. War also has political function. War also declared as individual war although some parts of societies were suffering (Dean G. Pruiitt and Jeffrey Z. Rubin 2004).

After the cold world war, the world was presented by various conflicts that happened in domestic (internal conflict). A study about conflict in the world after cold world war from 1989 to 1999 found that from 110 study, there only 7 conflicts were war between countries, meanwhile the others 103 are conflicts that happened domesticcaly. These conflicts cause by disagreement of part of the country status, authoritative government, country defention or branch between communities inside the country.

One kind of domestic conflict is separatism or self determination which occured in Aceh. Although each conflict has their own characteristic and feature, but most of them there are two strong factors identifed by conflict expert that join and formed the institution to discuss this kind of conflict. Identity is the main factor, there were groups of people inside group of identities based on people, religion, culture, languange and many other.

Second is deviding problem, that is amethod use in deviding of economical sources, social and politic in community.if there were a perception of unfair deviding occured or only efective oo certain community or identity, so from this point the potency of separatism conflict or self determination was created. So how this potency became an open conflict? Edwar E Azhar in his book Geunap Aceh (2010), wrote his frame theory Protacted Social Conflict stated three component that create potenct of conflict became oppressive conflict, there were:

1. First component is the community strategy and acted, there are identity collecting form proccess, organisation or asociation, there is or there is not a leader characteristic, the choose of political goal such as extended access, autonomy or separatism, tactics use in civiliant war or guerrilla war and space range also outsidenet. The new threatening for the safety and new chances that senses by communities, will pushed the mobilized and the appear of leadership was often determined the level of those community adversary.when it come to the separation demand, so the history of post autonomy politic, eventhough how long it last, it could be something that very important.

2. The second component is the state tactics and acts. This elements is very important element, theoritically in indivual command and government authority asociation facing the unity of policies choosing. Where in one hand contain various protection and oppression by force on the other hand. Based on political lost and economic output policies, so the policies took have tendency bring the oppression more than protection. This happened because the winner take all principles was occured in the country which has various communities.

3. Third component is the characterstic of conflict itself, where if conflict occured it caused the violent circle that wider. Because the violent in one side will responses also with violent by the other side and so on (Dean $G$ Pruitt and Jeffrey Z Rubbin, 2004)

That's happened with aceh conflict that became armed conflict and longterm war between Aceh Freedom Movement (GAM) and Indonesia Army (TNI) from 1976 to 2005 whith various military operation caused more than ten thousands of Acehness people became victims. 


\section{Discussion:-}

Gayoness highland is one of many districts in Aceh, was not free from longterm armed conflict influenced which devided into two phases there were phase before independence of Indonesia there were between Indonesia against Dutch and Japan colonialism, and the phase after Independence of Indonesia with some rebellion occured, there were DI/TII (Darul Islam/Tentara Islam Indonesia) in old orde and Aceh Freedom Movement/GAM rebellion in new orde.

Conflict between Indonesia Army (TNI) and Aceh Freedom Movement (GAM) caused by needed differenciated took place from 1976 made almost about 30.000 civilliants become victims. This action also known as Aceh Sumatra National Liberation Front (ASNLF). GAM leaded by Hasan Tiro for almost three decades, he live in swedia and had sweden nationality. GAM movement leaded by Hasan Tiro from 1976 to 2004 against government of the republic of Indonesia.

According to GAM, Aceh was free and independent country until dutch colonialism declared war against the liberated Aceh, therefore the authority transfered on Acehness between Dutch and Indonesia Government was illegal proccess or was not based on laws (look ASNLF, Independent proclamation of Aceh-Sumatra in Suara Aceh Merdeka Post, 15 November 1991).

Centralization of authority and economic exploitation (Aceh resources), the lost of culture or islamic culture of Aceh slowly, also the losing of place authority were the particular narration or reasons that breed by GAM later. By GAM these reasons were based to see that Aceh was allienated from "become Indonesia" project, that stand together in the beginning. Those narration were arranged, constructed and breed to compete with the narration of new orde construction. This narration bore froms of resistency with basic idea for this movement to freedom itself and separated from RI, because the government of Indonesia was incompetence to fullfill all the agreement from the republict founding contract.

Armed action were done to support perticular narration took place in the spot that full of new orde construction narration slowly. The increased of armed activities, big enterprise or police postion and army instance attacked also armed contacted with soldier, bore the dreadfull counter-insurgency acted from indonesia Government.

According to maintain the construction as the main reason, the government of Indonesia leaded by President Soeharto conducted military operation in 1989 which wider with determining and assembling of military operation territory to annihilated the GAM separatism movement. Nine year long military operation territory effectived from 1989 to 1997. Thousands of victims of Acehness who were killed, missing, raped, and sexual harrasment, or tortured left deep trauma (see Amnesty International 1993).

After formed, GAM got supported from Acehness people. International relationship also built continuily. Army force also constructed. How much GAM member. How it forces, international network and fund? GAM also had weapon factory and trained in Libya. Indonesia government gave an ultimatum until Mei 12, 2003 for GAM to hand over their weapon. But until the end of ultimatum, government of Indensia in Jakarta was not issue the decision as the sign of millitery operation in Aceh begun.

Perhaps, government of Indensia calculated the Indonesia Army (TNI) force there at that time. That was a doubtfull, that Indonesia Army (TNI) would defested by GAM through geurrilla war. Indirectly, this news sign the strenght of GAM army force. Actually the numbers of GAM member most of all are Acehness. That based on philosophy if people always under hard pressured, so all of people will rise to fight. And that was exactly happen in Aceh.

GAM resistances had beyond ordinary sympathy from Acehnes who oppressiones and mistread in longterm. Kompas reporter who had opportunity to met GAM higher commander and representative of Nanggroe Aceh, Teungku Abdullah Syafei (late) joked that all newborn baby in Aceh had their own AK-47 facilitated by GAM. They would be educated and trained as GAM army and soon went to war againts Indonesia Army (TNI).

In fact, the basic of GAM fought were done from both side, diplomatic and weapon. Diplomatic said directly leaded by Hasan Tiro from Swedia. International opinion were controlled from swedia meanwhile the army basic were controlled from it headquarter in North Aceh and Aceh Pidie border. All of GAM forces were operated from these areas, including all commands in numbers of places in Aceh and some other countries such as Malaysia, Pattani 
(Thailand), Moro (philipines), Afganistan and Kazasthan. But Indonesia Army (TNI) often tricked by GAM by changing the place of their headquarter frequently. In whole Aceh, GAM opened 7 millitary commands there were millitary command in Pase Pante Bahagia, Peurlak, Tamiang, Batee Ilek, Pidie, Aceh Darussalam and Meureum. Each of millitary command leaded by region commander.

Since it formed in 1976, GAM rapidly gave millitary education for its member. At least in nineteen eighty, thousand of Acehness youngsteer trained in millitary camp in Libya. At that time, president Libya, Moamar Khadafi conducted military training for separatism movement all over the world. Hasan Tiro successed included the GAM one of participant in that training.

GAM young cadet also had permitted to join the training in military camp in Kandahar, Afganistan leaded by Osama Bin Laden. The first phase training came in 1986 and kept on until the end of 1999. During military operational territory those dispatch were stagnant. But GAM soldier first force from 1995 to 1998 had got intensive training. When military operational territory withdrawed, the forces from Libya were pulled back to Aceh. It's about 5000 personil and became GAM first special forces or ellite calle Karades force (it's kind of Kopassus).

Entrances way to Libya were easier from Aceh. Those youngsteer sent from Malaysia to Libya. The other way from Aceh straight to Thailand and Afganistan and continuied to Libya. The third way from Aceh to south Philipine to Libya. These three important tracks almost always slip off from the reached of imigration officer, police and TNINavy patrol. In era of GAM commander Abdullah Syafei until Muzakir Manaf, GAM armies were consist of fight force, intelligent, police, widow force (forces of widow victim of military operation territory) and Karades (special forces), also tjut nyak dien force (female soldier). Gam vice commander Of Pase Akhmad Kandang (late) once ever claimed that member of GAM personel reached 70 thousand peoples. GAM member were 490 thousand. Those number included the victim of mlitary operational territory that reached 6.169 people.

During armed conflict between Aceh Freedom Movement (GAM) and Indonesia Army (TNI), Aceh became DOM (Millitary operational territory) that influenced educational and training activities to Gayoness. One of them was the training of making Gayoness water-pitcher handicraft that only once done by central Aceh Industrial Affair Department in 1989 participated by small number of gayoness water-pitcher craftman.

In that training, central Aceh Industrial Affair Department invited Mrs. Ainal Mardhiah, vessel craftman from Sigli to train Gayoness craftman to made porcelain or ashtray with spinned technique. Meanwilethe making of Gayoness pitcher which has branch or funnel had to use massage technique and could not be made using spin technique which use spin tool.

Weapon conflict caused the Gayoness pitcher craftman using igesing wood (any kinds of wood) or berkap (pine tree) or uyem (coffee tree) to burn the pitcher. Because of all these trees were collected from farm or forest in Gayo highland. During conflict era people afraid went to the farm or forest collected the firewood because of armed contact between GAM and Indonesia Army (TNI) in the city border or in deep of Gayoness highland forest.

As the replacement of firewood as vessel burner, so the Gayoness water pitcher craftmans use hull of rice (husk) or put it on the top of garbage as roasted material on earth surface or inside the shallow hole and made it steady with the pieces of vessel when the proccess of roasting. And then they put dried leaves, straw, coconut shell and pine skin among those pitcher that smoke function to strengthen pitcher structure and shined it colour. Next, the roasted proccess took 8 hours more or less until the flaming like cinder. After roasted proccess done, those pitchers were chill and kept on the wood shelf or kitchen so that it could be smoked every time till it color turned shiny black.

As there weren't any security and uncomfortable to live in Gayoness highland. There's many youngsteers went out from Gayo highland at that time to search jobs and avoided armed conflict.

After Tsunami and peace agreement between GAM and the government of the republic of Indonesia in 2005, there were many people went back to gayoness highland to re-open the farm or searched another jobs in constructed that district. Those activities made gayoness water-pitcher handicraft relive among gayoness people. Gayoness water-pitcher vessel handicraft were developed based on requested from the hooked parties such as industry Affair Department, National Handicraft Council(Dekranasda) and the community. 


\section{Summary:-}

The making of Gayoness water-pitcher handicraft during armed conflict still exist and carried out by the handicraft although the number of production outcome were drastically decreased. The decrease number during conflict between GAM and Indonesia Government was a consequences of fright and anxiety of the craftman to go outside and searched for good clay as the material of making Gayoness water-pitcher.

Armed conflict also caused drastically decreased of gayoness water-pitcher selling number. These decreased of selling number because only few or even none of tourists, domestic or international, would came to Gayoness highland during armed conflict between Aceh Freedom Movement (GAM) and Indonesia Army (TNI) in that place.

\section{Bibliography:-}

1. Al Chaidar, Sayed Mudhahar Ahmad, Yarmen Dinamika. Aceh Bersimbah Darah(Buku) 04 September 2008

2. Ahmadi, Abu, 1991, Sosiologi Pendidikan, PT Rineka Cipta Jakarta

3. Ahmad, Zakaryan dkk. 2008. Sejarah Perlawanan Aceh Terhadap Kolonialisme dan Impereliasme. Yayasan Pena Banda Aceh.

4. Amnesty International (1993), "Shock Therapy": Restoring Order in Aceh 1989-1993, London: Amnesty International, 23 July 1993

5. _ 2004. Indonesia, Operasi-operasi Militer Baru, Pola Lama Pelanggaran HAM Di Aceh

6. But Muchtar, Daya Cipta Dibidang Kriya, SENI: Jurnal Pengetahuan dan Penciptaan Seni, Volume 1/03, Oktober 1991

7. Edwin Thumboo, et all (eds.). 1985. Anthology of ASEAN Literature. The Poetry of Singapura. Singapura: Published Under Sponsorship the ASEAN Committe on Culture dan Information.

8. D. Kemalawati dan Sulaiman Tripa (eds.). 2005. Antologi Puisi Ziarah Ombak. Banda Aceh: Lapena.

9. Havilan, A William., (a.b) RG. Soekardijo, Hakekat Kebudayaan Jilid 1, Erlangga Jakarta 1995

10. Joyomartono, Mulyono, 1991, Perubahan Kebudayaan dan Masyarakat Dalam Pembangunan, Hal 10 IKIP Semarang Press

11. Kuntjaraningrat, 1988, Sejarah Antropologi, Hal 200-201, Jakarta UI Press

12. , 1990, Sejarah teori antropologi II, Universitas Indonesia(UI-Press) Jakarta.

13. Kaplan, David. Manners, Albert A, 1999; Teori budaya, Hal 80 Penerjemah Landung Simatupang, PUSTAKA PELAJAR, Yogyakarta.

14. Rohendi, Tjetjep Rohidi. 2000. Kesenian Dalam Pendekatan Kebudayaan. Hal 6 Accent Graphic Communication, Bandung.

15. Soedarso SP, 1999, Seni Kriya: Cabang seni yang sedang gelisah, SENI: Jurnal Pengetahuan dan Penciptaan Seni, Agustus 1999, Volume VII / 01

16. SP. Gustami, 2001: Wawasan seni kriya tradisional, Jurusan Kriya, Fakultas Seni Rupa, Institut Seni Indonesia Yogyakarta. 